\title{
Skjønn i praktisk barnevernledelse; Kollektiv prosess med organisatoriske begrensninger
}

\section{Sammendrag}

Til tross for $\varnothing$ kt fokus på både barnevernledelse og lederskjønn, er praktisk utøvelse av lederskjønn et lite utforsket område. Artikkelen omhandler skjønn i praktisk barnevernledelse. Oppmerksomheten er rettet mot hva barnevernleder gjør når hun praktisk utøver skjønn, og hva som påvirker og begrenser utøvelsen av lederskjønn. Datamaterialet er innhentet gjennom kvalitative intervjuer med barnevernledere. Studien viser at barnevernlederens skjønnsutøvelse i stor grad er en kollektiv prosess. Videre viser unders økelsen at barnevernlederen opplever et stort rom for skjønn, men at det er de organisatoriske forholdene som begrenser skjønnsutøvelsen. Egen kompetanse anses i liten grad å begrense skjønnsut øvelsen. Avslutningsvis drøfter forfatterne funnene samt peker på hva disse kan bety for en profesjonalisering av ledelse av barnevernet.

Nøkkelord: Skjønn, Lederskjønn, barnevernledelse, barnevern

\begin{abstract}
Despite increased focus on both child welfare leadership and discretion, the practical leadership discretion is an unexplored area. This article deals with discretion in practical child welfare leadership. Attention is directed at what the child welfare leader does when using discretion, and what affect and curtail discretion. The empirical data are based on qualitative interviews with child welfare leaders. The study shows that the child welfare leader's discretion is a collective process. Further, the child welfare leader experiences a large room for discretion, but the organizational conditions curtail discretion. Own competence is considered not to curtail discretion. Finally, we discuss the findings as well as the practical implications for a professionalizing of the leadership of the child welfare service.
\end{abstract}

Keywords: Discretion, Leadership discretion, Child welfare leadership, Child welfare service 


\section{Innledning}

Ledelse av barnevernet blir ofte beskrevet som svært krevende (McFadden, Campbell \& Taylor, 2014; Moe \& Gotvassli, 2016b; Moe \& Valstad, 2014; Toresen, 2014). Gjennom omfattende endringer $\mathrm{i}$ offentlig sektor har også barnevernledere fått et mer helhetlig lederansvar. Det innebærer $\varnothing \mathrm{kt}$ ansvar og ledelse innenfor områdene økonomi og personal i tillegg til barnevernsfaglig område (Døving, Elstad \& Storvik, 2016, s. 52). De senere årene har vi sett et økt fokus på ledelse i barnevernet. Nasjonalt er det formulert klare forventninger om at ledelse i barnevernet bør forbedres, og at lederkompetansen dermed må styrkes (Prop. 106 L, 2012-2013, s. 55; Riksrevisjonen, 2012; Statens Helsetilsyn, 2012). Det har blant annet ført til etablering av en nasjonal utdanning for barnevernsledere (Barne- ungdoms- og familiedirektoratet, 2017; Moe \& Valstad, 2014). Det finnes i dag lite forskning som gjelder ledelse av barnevernet (Shanks, Lundström \& Wiklund, 2015; Toresen, 2014). Den forskningen som finnes har i stor grad fokus på barnevernleders faglige ledelse, hvor blant annet beslutninger i barnevernsfaglige spørsmål og faglig skjønn har vært vektlagt (Kvello \& Moe, 2014; Moe \& Gotvassli, 2016a, 2017). Denne forskningen har stor verdi for å tydeliggjøre hvor komplekst barnevernfeltet er og hvor utfordrende ledelse av dette feltet kan være. Det finnes derimot lite empirisk forskning på det helhetlige lederskapet til barnevernlederen. Når ledelse ut $\varnothing v e s$ er bruk av skjønn en viktig del av det å gjøre vurderinger og fatte beslutninger, og skjønn har lenge vært et sentralt diskusjonselement innen ledelse (Kakabadse, Lee-Davies \& Kakabadse, 2009; Kirkhaug, 2017; Wangrow, Schepker \& Barker, 2015). Likevel er kunnskapen som finnes for mangelfull til å kunne gi grundige og relevante beskrivelser, forklaringer og vurderinger av lederskjønn. Utøvelse av skjønn trekkes fram som særegent for profesjoner (bl.a. Abbott,1988), men det finnes få studier som tar for seg de profesjonelles skjønnsutøvelse når de inntar en generell lederrolle (Berg, 2017). Det mangler også studier av selve prosessen hvor skjønnsbaserte avgjørelser tas (Shotter \& Tsoukas, 2014).

Denne artikkelen handler om barnevernleders bruk av skjønn i praktisk lederskap med utgangspunkt i barnevernleders helhetlige lederrolle. Artikkelen er empirinær og st $\varnothing$ tter seg på intervjuer med 20 kommunale barnevernsledere.

Formålet med artikkelen er å bidra til forståelse av og innsikt i praktisk ut øvelse av lederskjønn i lys av rammer og betingelser for barnevernledelse, samt bidra til et $\emptyset \mathrm{kt}$ kunnskapsgrunnlag om lederskjønn. Problemstillingen er: På hvilken måte utøves skjønn i praktisk barnevernledelse? । artikkelen undersøkes det i hvilke sammenhenger lederskjønn utøves, hva som påvirker skjønnsut øvelsen og hva barnevernleder opplever som begrensninger for ut $\varnothing v e l s e$ av lederskjønn. Videre undersøkes det hva barnevernleder gjør når hun praktisk utøver skjønn. 


\section{Teoretisk rammeverk}

Innenfor ledelseslitteraturen har man tradisjonelt vært opptatt av forskjellen mellom administrasjon og ledelse. Ledelse har fokusert på det relasjonelle, mens administrasjon handler om tilrettelegging ved å fastsette mål, verdier, rammer og regler samt kontrollfunksjon (Kirkhaug, 2015; Sullivan, 2016). Et begrep som ofte brukes på disse funksjonene er styring. Nyere ledelseslitteratur har i stor grad gått bort fra dette skillet, og har tatt i bruk begrepet lederskap. Lederskap inkluderer både administrative og relasjonelle funksjoner. Det omfatter utvikling og ivaretakelse av medarbeidere, det kollegiale settes foran det individuelle og man tar hensyn til alle interessenter (Kirkhaug, 2015). Den relasjonelle siden av lederskapet har likhetstrekk med profesjonsut $\varnothing v e l s e$ ved at arbeidet er preget av usikkerhet og med et stort innslag av skjønn (Døving et al., 2016). Nyere lederskapstilnærminger omfatter lederskap i profesjonelle og sosiale kontekster, og i denne sammenhengen oppfattes lederskap som en kompleks, paradoksal og situasjonsbetinget funksjon (Kirkhaug, 2013, 2015).

Barnevernet har en særegen posisjon i norsk oppvekst- og omsorgspolitikk, og gjennom lovverket har barnevernet fått vide fullmakter. Ledelse av kommunalt barnevern beskrives som krevende fordi barnevernets hverdag ofte preges av kompleksitet, usikkerhet og belastninger (Moe \& Gotvassli, 2016a, s. 196,197). Det er i mange tilfeller usikkert hva som blir konsekvensene av de handlingsvalg som gjøres. Colby Peters $(2018$, s. 32) peker på tre ting som kjennetegner ledelse innen sosialt arbeid. Lederskapet inneholder et sterkt følelsesmessig aspekt og det bygger i stor grad på samarbeid med andre. Lederskapet er styrt av formålet med tjenestene, som er å sørge for individuell og samfunnsmessig velferd. Lederne må dermed implementere og følge opp statlige og organisatoriske retningslinjer og pålegg (Popa, 2012). Barnevernlederen har ansvar for tjenestens strategiske, faglige og verdimessige plattform, og skal ivareta et vidt spenn av hensyn og krav. Ofte kan slike krav gå på tvers av hverandre og dilemmaer oppstå. Krysspresset mellom ulike styringskrav pekes på av flere (Agevall, 2000; Gaim \& Wåhlin, 2016; Hood, 1991; Hood \& Peters, 2004; Kirkhaug, 2015; Kvello \& Moe, 2014; Pettersen \& Solstad, 2014; Shanks et al., 2015; Wällstedt \& Almqvist, 2015).

Skjønn er ikke et entydig begrep. Utøvelse av skjønn trekkes fram som særegent for profesjoner (Abbott, 1988; Freidson, 2001; Molander \& Terum, 2013b), og er da gjerne knyttet til utøvelse av et profesjonelt eller faglig skjønn. Skjønn og utøvelse av skjønn utgjør en stor del av barnevernleders hverdag, både i barnevernfaglige vurderinger og i ledelsesfaglige beslutninger. Skjønnsbegrepet kan sees ut fra to hovedbetydninger, strukturell og epistemisk forståelse av skjønn (Grimen \& Molander, 2008). I en strukturell forståelse er skjønn et vernet rom for valg eller beslutninger. Man kan sammenligne skjønn med hullet i en smultring, hvor hullet utgjør skjønnet og selve smultringen 
utgjør restriksjoner som rammer inn skjønnet (Dworkin, 1978). En epistemisk forståelse av skjønn legger til grunn at skjønn er en kognitiv aktivitet (Grimen \& Molander, 2008). Formålet med skjønnsut øvelsen blir da å skille noe fra noe, og for å komme fram til en begrunnet konklusjon om hva som bør gjøres (Grimen, 2009). Skjønn kan sies å være praktisk argumentasjon under uklare omstendigheter.

Faglig skjønn og skjønnsut øvelse i barnevern og sosialt arbeid er rikt beskrevet fra ulike perspektiver. Bjørnebekk (2010) snakker om hvilket kunnskapssyn som ligger til grunn for det barnevernsfaglige skjønnet. Andre, som for eksempel Evans og Harris (2004), Molander (2011), Olaison, Torres og Forssell (2018) og Nyathi (2018), unders $\varnothing$ ker skjønn som element i beslutningstaking i profesjonelt arbeid. I ledelseslitteraturen understrekes skjønn som en viktig egenskap ved ledelse, og det å ut $\varnothing v e$ ledelse innebærer bruk av lederskjønn (Evans, 2011; Hutzschenreuter \& Kleindienst, 2013; Kakabadse et al., 2009; Kirkhaug, 2017; Shotter \& Tsoukas, 2014). Som følge av økende krav om endring, sterke innslag av uforutsigbarhet, kompleksitet og dilemmaer, samt uklare referanser for beslutningene, har skjønn fått økende oppmerksomhet i lederskapssammenheng (Hagebakken \& Nilsen, 2017, s. 95; Olaison et al., 2018). Ledere bruker skjønn for å ta beslutninger og for å handle i ulike organisatoriske kontekster. Lederskjønn formes av både organisatoriske krav og restriksjoner, samt individuelle forutsetninger. En lederhverdag med $\varnothing \mathrm{kt}$ tidspress og forventninger om at komplekse beslutninger må tas og implementeres nesten umiddelbart utfordrer lederskjønnet. Lederskjønnet kan derfor hjelpe lederen å ta riktige beslutninger gjennom å balansere følelser og disiplin, effektivitet og tilpasning, langsiktig og kortsiktig perspektiv, samt stabilitet og endring (Espedal \& Kvitastein, 2012). Ofte framsettes det at stort rom for skjønn er en utfordring, og at skjønnet dermed må begrenses og erstattes med regler og rutiner (Espedal, 2015). Andre er uenige i dette og mener at flere regler og rutiner ikke nødvendigvis innskrenker skjønnet (Evans, 2011; Evans \& Harris, 2004; HøybyeMortensen, 2015; Nyathi, 2018; Ponnert \& Svensson, 2016). Goodin (1986) trekker fram at bruk av skjønn kan medføre manipulering og utnyttelse, samt vilkårlighet og uforutsigbarhet $\mathrm{i}$ saksbehandling. Det kan bidra til usikkerhet om utfall og en privatisering av beslutningstaking. Disse utfordringene ligger innbakt i skjønnsbrukens natur, og vil kun løses ved å fjerne muligheten til å bruke skjønn.

Mye av det som er skrevet om skjønn og ledelse handler om strukturelt skjønn. Vi finner også definisjoner av lederskjønn hvor skjønn knyttes til taus kunnskap og praktisk visdom eller klokskap (Shotter \& Tsoukas, 2014; Tredget, 2010). I denne artikkelen tar vi utgangspunkt i Kirkhaugs klargjøring og avgrensing av lederskapsskjønn i organisasjoner (Kirkhaug, 2017, s. 35), og ser barnevernsleders praktiske skjønnsutøvelse ut fra to perspektiver; betingelsesperspektivet og prosessperspektivet. 
Betingelsesperspektivet kan knyttes til strukturelt skjønn, og omhandler forutsetningene for å utøve skjønn. Det utgjøres av både personlige og organisatoriske forutsetninger. Personlige forutsetninger kan være personlighet og ulike mentale kapasiteter. Mentale kapasiteter kan være intelligens, kompetanse og kreativitet. Praktisk sunn fornuft og klokskap beskrives også som en mental kapasitet og utgjør en personlig forutsetning for skjønnsut øvelse. Organisatoriske forutsetninger kan være organisasjonsformer, organisasjonskultur og det handlingsrommet ledere har til å utøve ledelse og fatte beslutninger (Kirkhaug, 2017).

Prosessperspektivet utgjør den epistemiske dimensjonen og handler om selve skjønnsprosessen. Det vil si hva som foregår bevisst og ubevisst når skjønn utøves. Prosessperspektivet fokuserer på hva som gjøres konkret i skjønnsutøvelsen, og om skjønnsutøvelsen er forankret i analytiske og eksplisitte eller i intuitive og tause prosesser. Skjønn er ofte et resultat av både bevisste/eksplisitte og intuitive prosesser. Bevisste prosesser handler om å identifisere og diagnostisere, søke etter alternativer for løsning, evaluering og ta endelig valg. Intuitive prosesser er erfaringsbasert, slik som taus kunnskap, sanser og magefølelse (Kirkhaug, 2017).

Dersom vi tar utgangspunkt i vår definisjon av lederskap som situasjonsbetinget og kontekstavhengig vil en slik inndeling for å forstå lederskjønn være fruktbar. Hutzschenreuter og Kleindienst (2013) framhever at lederskjønn påvirkes av personlige, relasjonelle og situasjonelle faktorer, og at konteksten for utøvelse av ledelse anses som viktig. Skjønnet framstår heller ikke som statisk, men endrer seg kontant avhengig av situasjonen (Evans \& Harris, 2004).

\section{Metode og gjennomføring}

For å forstå hvordan barnevernslederen utøver sitt skjønn i praktisk lederskap har artikkelen et hermeneutisk utgangspunkt. Vi ser på ledelse og skjønnsutøvelse som kontekstavhengig ved at begge utøves i praksis innenfor ulike rammer. Ledelse i barnevernet har også en individuell dimensjon gjennom barnevernlederens egen fortolkning av sin rolle. Konteksten hvor barnevernleder utøver sin ledelse kan ikke kun betraktes som en objektiv virkelighet utenfor barnevernlederen. Konteksten inneholder også et subjektiv element gjennom barnevernlederens aktuelle tolkning av den (Hollis, 2002). Dermed vil lederpraksis kunne variere ut fra kontekst (Mintzberg, 2001). Ved å knytte kontekstbegrepet til meningssammenheng vil vi kunne forstå hva praktisk barnevernledelse og skjønnsutøvelse er og hvordan det foregår. Utøvelsen av både ledelse og skjønn vil være vevd inn i normer og kulturelle verdier (Askeland, 2016; Askeland, Blomander \& Aasen, 2015; Højberg, 2014). Barnevernslederens skjønnsutøvelse og ledelsespraksis må derfor forstås ut fra den konteksten disse utøves i, som er kommunalt barnevern. 
Datamaterialet er innhentet gjennom semistrukturerte kvalitative intervjuer. Det er en metode som er velegnet til unders $\varnothing$ kelser hvor man $\varnothing$ nsker en eksplorativ tilgang til data (Justesen \& Mik-Meyer, 2010). Hensikten har vært å få barnevernlederne til å beskrive sine erfaringer og handlinger så presist som mulig (Kvale, 1990), og dermed kunne forstå den praktiske dimensjonen i skjønnsutøvelsen (Askeland et al., 2015; Kelly \& Bakr Ibrahim, 1991). Det kvalitative forskningsintervjuet er i overensstemmelse med en hermeneutisk forståelsesform (Kvale, 1990). Ledelsesforskningen har tradisjonelt basert seg på en omfattende bruk av ulike kvantitative unders $\varnothing$ kelser, og har i mindre grad vært basert på kvalitativt materiale (Askeland et al., 2015, s. 4).

Utvalget består av 20 kommunale barnevernsledere, og presenteres i følgene oversikt:

[Tabell 1; Presentasjon av utvalget omtrent her]

Barnevernstjenestene inkludert i utvalget varierer i størrelse, og betjener en befolkning fra omtrent 5500 innbyggere for de minste og opp mot 80000 innbyggere for de største. Det gjenspeiles i organisering og antall ansatte som barnevernsleder har ansvaret for. Lederne er geografisk plassert over hele landet.

[Figur 1; Geografisk fordeling av deltakerne omtrent her]

Rekruttering av barnevernsledere ble gjennomført på ulike måter. Det ble tatt direkte kontakt basert på kontaktinformasjon fra den enkelte kommunes nettside. De første 20 fikk henvendelse ved brev, med oppfølgende henvendelse på e-post. Dette ble endret til at det bare ble sendt e-post direkte til barnevernsleder. For å nå ut til så mange barnevernledere som mulig ble medlemslisten til Norsk barnevernorganisasjon (NOBO) brukt i rekruttering. Medlemslisten var tilgjengelig på NOBOs hjemmeside (Norsk barnevernlederorganisasjon, 13.04.2018). Totalt ble 128 barnevernsledere kontaktet. Medlemslisten dekket både nåværende og tidligere ledere, noe som førte til at e-poster også ble sendt til ugyldige e-postadresser. Vi inkluderte fortløpende de som ønsket å delta inntil vi fikk et datamateriale som var stort nok til å gi en forståelse av barnevernsleders ut $\varnothing$ velse av lederskjønn, i tråd med Thagaard (2016, s. 65) sin beskrivelse av metningspunkt når inkludering av flere enheter ikke bidrar til ytterligere forståelse.

Intervjuene ble gjennomført i tidsrommet juli 2017-juni 2018, 8 ved bes $\varnothing \mathrm{k}$ hos barnevernsleder og 12 ved telefonintervju. Kvalitative forskere baserer seg generelt på ansikt-til-ansikt intervjuer når semistrukturerte intervju skal gjennomføres. Telefonintervju blir gjerne sett på som passende for 
korte, strukturerte intervju eller i situasjoner hvor ansikt-til-ansikt intervjuer ikke er mulig. Vi ser derimot at bruk av telefon ved semistrukturerte intervju er økende (Ward, Gott \& Hoare, 2015), og det ikke uvanlig å finne kvalitative studier i ulike disipliner hvor alle eller noen av intervjuene er utført ved bruk av telefon (Irvine, Drew \& Sainsbury, 2012). Sammenligninger gjort av kvaliteten på data samlet inn ved hjelp av begge metodene i en og samme unders $\emptyset$ kelse viser liten forskjell mellom de to metodene (Sturges \& Hanrahan, 2004). Man bør likevel være bevisst på forskjellene mellom de to intervjutypene. Den største forskjellen mellom telefonintervju og ansikt- til-ansikt intervjuet er fraværet av visuelt møte. Mangel på visuell kontakt kan legge begrensninger på utvikling av forståelse og det å få til et «naturlig» møte, elementer som er ansett for å være viktig for å generere rike kvalitative data (Novick, 2008). Vi har forsøkt å ivareta dataenes troverdighet (Tracy, 2010) og konsistens (Olsen, 2003) gjennom å etterstrebe «tykke beskrivelser» som går i dybden, har rikelig med konkrete detaljer og redegjør for kulturelt situerte meninger (Tracy, 2010). Uartikulert kunnskap som nikk og andre artefakter som krever en ansikt-til-ansikt situasjon har naturlig falt bort i telefonintervjuene, mens humor, stillhet og andre artefakter som ikke krever visuell kontakt ivaretas også i telefonintervjuene.

For å ivareta et geografisk spredt utvalg av barnevernsledere ble telefonintervju valgt for de som var lengst unna. Det ble valgt både av hensyn til tidsbruk og reisekostnader. Besparelse i reisekostnader og tidsbruk trekkes fram som en av fordelene med telefonintervju (Irvine et al., 2012; Sturges \& Hanrahan, 2004). Ulike unders $\emptyset$ kelser viser at semi-strukturerte kvalitative intervjuer egner seg godt til telefonintervju, men at de bør kombineres med kommunikasjon på forhånd, for eksempel gjennom e-poster (Trier-Bieniek, 2012). I dette studiet ble alle barnevernlederne kontaktet på forhånd og avtaler om intervju ble gjort på e-post. Før intervjuet fikk alle intervjupersonene oversendt beskrivelse av forskningsprosjektet hvor formålet med intervjuene var redegjort for. Dette ble repetert ved oppstart av intervjuet. I denne studien er det ikke forskjell i lengde eller detaljrikdom mellom ansikt-til-ansikt intervjuene og telefonintervjuene. Intervjuene varte fra 50-90 minutter. Bytte av medium for intervju førte ikke til at innholdet i intervjuet endret seg. Telefonintervju kan gjøre det vanskelig for intervjueren å gå i dybden for å få med flere detaljer eller aspekter ved det intervjupersonen formidler (Sweet, 2002). I alle intervjuene var det mulig å gå i dybden og avklare poeng som intervjupersonen kom med uavhengig om intervjuet foregikk over telefon eller ansikt-til-ansikt. Alle intervjuene ble tatt opp ved hjelp av diktafon, og transkribert i etterkant. Alle barnevernlederne fikk tilsendt utskrift av intervjuene for gjennomlesing og mulighet for endring og tilføyelser i etterkant. Det er ikke mulig å skille telefonintervjuene fra ansikt-til-ansikt intervjuer ut fra utskriftene. Vi ser derfor ikke at det er noen systematiske skjevheter i datamaterialet som skulle være utslagsgivende for analysen. Undersøkelsen er godkjent av Norsk senter for 
forskningsdata og er gjennomført i tråd med etiske retningslinjer om samtykke og mulighet for å trekke seg uten begrunnelse. I presentasjonen av analysene er deltakerne anonymisert.

\section{Analysestrategi}

Analysen av dataene er lagt opp som tematiske analyser. Tematisk analyse er en prosess for koding av kvalitativt datamateriale. Et tema er et mønster funnet i datamaterialet som minimum beskriver og organiserer mulige observasjoner eller som maksimum tolker aspekter ved fenomenet (Boyatzis, 1998). Ifølge Thagaard (2016) er det et grunnleggende premiss for temasentrerte analyser at vi har informasjon fra alle deltakerne om de samme temaene, og hvor tekstene vi analyserer følger en ordnet struktur. I denne studien er alle intervjuer gjennomført slik at alle deltakerne i unders $\varnothing$ kelsen kommenterer de samme spørsmålene. I analysen ble kodene utviklet ut fra forskningsspørsmålene og teoretisk utgangspunkt, såkalt teoridrevet koding. Kodene ble lagt inn i data- og analyseverktøyet NVivo som noder. Under kodingen med forhåndsdefinerte koder ble induktive koder identifisert og knyttet til deler av data som beskrev nye tema som var observert $i$ teksten. Kodene ble enten separert fra de forhåndsdefinerte kodene eller de utvidet en allerede eksisterende kode.

Temasentrert analyse kritiseres for at den ikke ivaretar et helhetlig perspektiv ved at utsnitt fra tekster fra de ulike deltakerne løsrives fra sin opprinnelige sammenheng (Thagaard, 2016, s. 181). For å unngå en slik fragmentering har vi vurdert utsagnene fra hvert enkelt intervju opp mot intervjuet som helhet. Vi har også gjort analyser av sammenhengen mellom temaene, noe vi mener gir grunnlag for en helhetlig forståelse av datamaterialet.

I presentasjon av deltakerne er de gruppert ut fra de kategoriene vi har anvendt (kjønn, erfaring, grunnutdanning, lederutdanning og befolkningsgrunnlag). Antall års erfaring som barnevernleder har vært den styrende kategorien. For å opprettholde anonymisering er sitatene som brukes knyttet til disse gruppene, og ikke til hvem de faktisk er. Gruppene har vi gitt personnavn.

[Tabell 2; Presentasjon av deltakerne omtrent her]

\section{Resultat og analyse}

Analysene vi har gjort av datamaterialet blir presentert i to deler, og viser at datamaterialet deler seg mellom det vi kaller kontekst og rammer og hva barnevernleder praktisk gjør når hun utøver skjønn. I første del har vi brukt hva som hemmer og fremmer skjønn i ledelse som katalysatorer for analysen. I andre del er intuitive/tause og bevisste prosesser anvendt som katalysatorer for analysen. 


\section{Kontekst og rammer}

Barnevernlederne beskriver sin lederhverdag som hektisk og arbeidsom. Den er krevende, følelsesladet og uforutsigbar med hyppige fokusflyttinger og stor møteaktivitet. De fleste praktiserer "åpen $d \varnothing r$ ” for å være tilgjengelig, noe som fører til mange avbrytelser i løpet av dagen. Veiledning av de ansatte i barnevernsfaglige problemstillinger, samt oppfølging av personalet tar tid og fokus.

Samtidig beskriver de hverdagen som interessant, spennende og givende. Barnevernlederen fungerer i stor grad som en tilrettelegger for at arbeidsdagen skal flyte så godt som mulig for alle. I utøvelse av sitt lederskap bruker barnevernlederen skjønn, og det er noe alle sier at de bruker "hver dag" eller "hele tiden". Anita beskriver det slik;

Jeg tror at en stor del av hverdagen går til å bruke skjønn. Det hørtes litt rart ut. Jeg har ikke tenkt over det. Men når du spør sånn direkte så tenker jeg at jeg gjør det i stor grad.

Vi ser at skjønn er noe som brukes hele tiden og i mange situasjoner, og at skjønnsutøvelse utgjør en del av konteksten for ledelse i barnevernet. Barnevernlederne opplever at rommet for å bruke skjønn i sin lederhverdag er stort. En av lederne framhever at dette rommet noen ganger oppleves som for stort.

\section{Hva påvirker barnevernleders utøvelse av skjønn?}

Barnevernlederne ga utfyllende og grundige svar på hva de mener påvirker deres skjønnsutøvelse. Svarene til barnevernslederne er gruppert i tre kategorier; usikkerhet om utfall av skjønnsut øvelsen, ressurser og ulike preferanser og manglende rammer. Kategoriene presenteres i rangert rekkefølge ut fra hva flest barnevernsledere vektla i sine svar.

Barnevernlederne mener det påvirker skjønnsutøvelsen at man ikke vet hvilke konsekvenser en beslutning basert på skjønnsutøvelse får. De er usikker på hva som er riktig konklusjon, og usikkerheten knyttes til at det sjelden finnes noen fasitsvar innen barnevern. Det er mange ukjente faktorer og lederne opplever ofte forventninger fra andre om å kunne presentere et fasitsvar. Lederne opplever dilemmaer i forhold til hva som bør vektlegges fordi krav og forventninger ofte er kryssende. Det gjør det utfordrende å konkludere.

Ressurser som tid, økonomi og personal påvirker skjønnsutøvelsen. Barnevernlederne mener at mangel på ressurser virker inn på skjønnsutøvelsen i form av manglende grundighet og dermed et svekket kunnskapsgrunnlag for å ta beslutninger. Det fører til en emosjonell belastning i form av stress og usikkerhet knyttet til skjønnsutøvelse.

Barnevernlederne trekker fram at ulike preferanser og manglende rammer kan påvirke skjønnsutøvelsen. Ulik erfaringsbakgrunn innebærer at man som leder vil vektlegge ulike ting, og at 
det påvirker hvordan man forklarer og forsvarer de skjønnsmessige vurderingene overfor andre. Lederne mener at et diffust lovverk og uklare retningslinjer også påvirker skjønnsutøvelsen gjennom at rommet for skjønnsutøvelse blir for stort. Det pekes på at mangel av "et felles språk" er en utfordring i utøvelsen av lederskjønn. Et eksempel som trekkes fram er at en ulik forståelse av sentrale begreper, som for eksempel barnets beste og forsvarlighet, kan påvirke utøvelsen av skjønn.

\section{Begrensninger på skjønnsutøvelsen}

I tillegg til at barnevernlederne beskriver hva som påvirker skjønnsutøvelsen, opplever de også en del forhold som de mener begrenser deres mulighet for å bruke lederskjønn. Begrensningene som lederne opplevde var disse; tid, lovverk, regler og retningslinjer, manglende eller begrenset tiltaksapparat, økonomi, intern kultur og kritikk fra samarbeidsparter. Noe av det lederne mener påvirker skjønnsutøvelsen oppleves også som begrensninger.

Tid oppleves som en begrensing av skjønnsutøvelsen til en viss grad. Ved høyt arbeidstempo og stort press må ting skje raskt. Barnevernlederne har ansvaret for at tidsfrister skal overholdes, noe som av og til oppleves som vanskelig fordi man ikke har alle opplysningene man trenger for å ta en beslutning. Informasjon må innhentes fra ulike instanser, og tidsaspektet gjør at man av og til må gjøre skjønnsut $ø$ velsen ut fra ufullstendig informasjon.

Lovverk, regler og retningslinjer begrenser også skjønnsutøvelsen. Barnevernlederne opplever en $\varnothing \mathrm{kning}$ i regler og retningslinjer, og $\emptyset$ kte krav til hvordan arbeidsoppgaver skal utføres. Dag sier det slik; "Det blir et 'overfokus' på å gjøre ting riktig framfor å gjøre de riktige tingene." Barnevernlederne mener at de politiske føringene og dermed kravene til barnevernet har blitt tydeligere. Det er med på å ramme inn skjønnet. Det er blitt tydeligere hva som er tillatt/ikke tillatt. En barnevernleder nevner klare føringer og forventninger om færre omsorgsplasseringer som et eksempel, og opplever dette som en begrensning for seg som leder. Det gjør at man føler et press for å fatte "riktig" beslutning.

Barnevernlederne er samstemte i at et manglende eller begrenset tiltaksapparat legger begrensinger på skjønnsutøvelsen. Barnevernlederne forteller at de ut fra skjønnsvurderingen ofte ender med å velge det nest beste alternativet fordi det $\emptyset$ nskede tiltaket ikke finnes blant de tiltakene man har til rådighet.

$\varnothing$ konomi oppleves som en klar begrensning. Flere barnevernsledere refererer til dårlig kommuneøkonomi. Det innebærer klare krav om økonomistyring. Dårlig kommune økonomi legger begrensninger på de skjønnsmessige vurderingene som gjøres i forhold til både barnevernfaglige og personalmessige tiltak, slik som sertifisering av ansatte, videreutdanning og kompetanseheving generelt. Intern kultur kan virke begrensende på skjønnsutøvelsen ved at de ansatte takler 
skjønnsutøvelse ulikt og noen føler seg lett urettferdig behandlet. Kritikk fra samarbeidsparter både internt og eksternt oppleves ofte som urettmessig, og kan virke begrensende på barnevernleders skjønnsut øvelse.

\section{I hvilke sammenhenger utøves skjønn?}

Barnevernleder bruker skjønn stort sett hele tiden, og det er to områder eller situasjoner som skiller seg ut når det gjelder omfang av skjønnsbruk; skjønn i personalsituasjoner og skjønn i komplekse barnevernsfaglige saker.

De fleste barnevernlederne fremhever at skjønn brukes i situasjoner som gjelder personalet. Som eksempler nevnes ansettelsessaker, fordeling av saker mellom ansatte, oppfølging av personalet med faglig veiledning og i personalsaker generelt. Dag fremhever følgende: "Ja, viktigste jobben, viktigste skjønnsutøvelsen jeg gjør, er jo når jeg skal ansette folk. Og der er det jo ikke noe oppskrift." Anita formulerer seg slik:

Ja, det er nok litt vanskelig å si noe om det. For man driver jo ikke akkurat og vekter det da. Jeg tror jo at det er i den menneskelige jobben, altså i forhold til personaloppfølgning og personaljobbing i det hele tatt, og i forhold til barnevernssaker. Det er vel der jeg bruker mest skjønn.

Det andre området hvor skjønn ble mest brukt var i situasjoner som omhandlet komplekse og vanskelige problemstillinger. Cathrine beskriver slike situasjoner som situasjoner "der du kunne ønske at du hadde sluppet å bruke skjønn." Det er situasjoner som er så tunge, alvorlige og komplekse at du skulle ønske at du slapp å bruke skjønn og at det fantes et svar med to streker under. Sakene som trekkes fram av barnevernlederne er barnevernssaker som er akutt eller hvor omsorgsovertakelse vurderes. I begge typer saker skal det gjøres valg og tas avgjørelser av alvorlig karakter.

Felles for situasjonene hvor barnevernslederne sier de bruker mest skjønn, er at skjønn brukes i situasjoner der det handler om mennesker eller mellommenneskelige relasjoner. Skjønn brukes altså mest i situasjoner som omhandler det relasjonelle, ikke det materielle. Ingen av barnevernslederne framhever økonomi som et område hvor de bruker mye skjønn, og Berit formulerer seg slik:

Altså, det er jo i forhold til faget man bruker skjønnet mest. Det er jo ikke i forhold til økonomi, for å si det sånn. Men selvfølgelig så gjør man jo også det i forhold til personaloppfølgning.

\section{Hva gjør barnevernleder når hun praktisk ut øver lederskjønn?}

For å forstå hvordan barnevernlederne utøver skjønn i praktisk ledelse er det fornuftig å klargjøre hva de legger i begrepet skjønn. Skjønn og skjønnsbegrepets innhold var vanskelig for barnevernslederne å beskrive. Innholdet i skjønnsbegrepet var noe de fleste ikke hadde reflektert over. Noen fant det vanskelig å beskrive, og mente at skjønn rommet så veldig mye. Til tross for dette 
kan vi gjøre en oppsummering av barnevernledernes oppfatning av hva skjønn er. De oppfatter skjønn som noe subjektivt og som ikke er statisk. Skjønn utgjøres av sunn fornuft, kompetanse og erfaring. Det handler om både fagkunnskap, faktakunnskap, erfaringskunnskap og kunnskap om lover og rammeverk. Det innbefatter også relasjonskompetanse. Skjønn er også vurdering og veloverveide beslutninger, og det gir rom for kreativitet. En av barnevernslederne oppsummerer det slik: “skjønn er summen av alt."

Ut fra barnevernsleders forståelse av skjønnbegrepet og hennes beskrivelse av de situasjoner hvor skjønn brukes mest, er det interessant å se hvordan lederskjønn utøves i praksis. Hva gjør barnevernlederen når hun utøver skjønn? Hvilke arbeidsoppgaver eller prosesser foregår når skjønn utøves? Hva består skjønnsutøvelsen av? Barnevernslederne ble spurt om hva de gjør når de utøver skjønn, og ble bedt om å gi konkrete eksempler.

I tabell 1 har vi oppsummert barnevernledernes beskrivelser av hva de konkret gjør når de ut øver skjønn. Barnevernledernes utsagn er plassert i ulike kategorier og rangert ut fra hva flest barnevernsledere vektla i sine svar. Tallene i parentes viser rangering ut fra vektlegging. Beskrivelsene er delt inn i bevisste og intuitive prosesser.

[Tabell 3; Barnevernsleders praktiske skjønnsutøvelse omtrent her]

Barnevernslederne bruker sine erfaringer når de utøver skjønn. Dag beskriver det slik:

Hva jeg gjør? Det er jo en sånn mer eller mindre taus kunnskap da [...] Jeg bruker jo min kompetanse og min erfaring og prøver å bruke de enkelte faktorene som jeg får kjennskap til i det problemet jeg skal håndtere. Og finner ut hvordan jeg skal bruke min erfaringskunnskap og min kompetanse, og se litt sånn distansert på det da.

Barnevernslederne snakker med andre når de utøver skjønn. Det kan være ledergruppa, tillitsvalgte, hovedverneombud, samarbeidsparter eller saksbehandlere. Oftest snakker de med ledergruppa eller nestleder. De drøfter den konkrete saken, de får innspill og mottar andres vurderinger. De lytter og får råd. Barnevernlederne setter seg inn i fakta i saken, og tilegner seg kunnskap om saken. De fors $\varnothing$ ker å se saken fra ulike sider og ut fra ulike perspektiv, og fors $\varnothing$ ker å redusere usikkerheten. Barnevernslederne forholder seg til ulike rammer, som for eksempel lovverk og retningslinjer. Noen trekker også fram etikk og kultur i denne forbindelsen. Barnevernlederne gjør vurderinger når de ut $ø$ ver skjønn. De tenker, reflekterer og sorterer vekk det uvesentlige. De vekter ulike faktorer, konkretiserer, systematiserer og analyserer. Det gjøres avveininger og i noen grad skiftliggjøres momenter underveis i skjønnsprosessen. Berit beskriver hva hun gjør: 
om [...] Også blir det jo da en vekting av ulike faktorer, også er det de andre som er med i drøftingene, enten de som kom med problemet eller noen andre, så blir det da hva som blir vektlagt, hvilke perspektiver er det som står sterkest.

Barnevernslederen bruker fag og faglige teorier i sin skjønnsutøvelse, og har fokus på den beslutningen skjønnsprosessen skal føre til når det brukes skjønn. Utøvelse av skjønn medfører at det gjøres individuelle tilpasninger og det tas individuelle hensyn i forhold til hvem og hva saken gjelder. I noen tilfeller venter man med å handle og bruker tid, og "sover på det". I skjønnsutøvelsen brukes også sunn fornuft og magefølelsen.

\section{Diskusjon}

I denne delen drøfter vi funnene fra forskningsspørsmålene på et overordnet nivå. Med utgangspunkt i prosessperspektivet drøfter vi hva som foregår når barnevernleder utøver skjønn. Videre drøfter vi hva barnevernleder opplever som begrensningene for sin skjønnsutøvelse. Det drøftes ut fra betingelsesperspektivet, hvor også barnevernleders handlingsrom og rom for skjønnsutøvelse berøres.

\section{Hva foregår når skjønn ut øves? Skjønn som kollektiv analytisk prosess.}

Barnevernlederens skjønnsut øvelse kan sies å være av en sosial og kollektiv karakter, og består i hovedsak av bevisste prosesser. En viktig del av barnevernlederes skjønnsut $\varnothing v e l s e$ er å snakke med andre, gjerne lederteam eller nestleder. Her drøftes sakene og man får hjelp til å belyse saken fra ulike perspektiv. Ved å snakke med andre, sette seg inn i sakens fakta, se saken fra ulike perspektiv samt gjøre vurderinger ut fra fag og faglige teorier, vektlegges de analytiske og eksplisitte prosessene. I barnevernleders tilfelle er disse prosessene i stor grad av kollektiv karakter. Barnevernlederen framhever at det å lytte til og lære av andre er sentralt. Barnevernlederen ut $\varnothing v e r$ skjønn sammen med sine ansatte, og skjønnsutøvelsen blir mer en kollektiv aktivitet enn en individuell prosess. Kollektivet utgjør et holdepunkt for skjønnsutøvelse i form av barnevernleders meningsutveksling, diskusjoner og forhandlinger med andre. Lederteamet og kollegiet ser ut til å være et viktig holdepunkt for skjønnsut øvelse, noe som også understøttes av Moe og Gotvassli (2017).

Hvordan kan vi forklare at det er de analytiske og eksplisitte prosessene som vektlegges $\mathrm{i}$ barnevernleders skjønnsutøvelse, og at disse prosessene i hovedsak er av kollektiv karakter? En forklaring kan være at skjønnsut øvelsen i stor grad er knyttet til fag og faglig skjønnsutøvelse. Kollektiv skjønnsut øvelse er situasjons- og kontekstavhengig, og kobles ofte til ut øvelse av faglig skjønn i kontekster hvor man behandler komplekse saker og der fasitsvarene er få (Andersen, Moldenæs \& Torsteinsen, 2017). Det sammenfaller med beskrivelsene barnevernleder gir av egen 
lederhverdag. De fleste barnevernlederne har bakgrunn som enten barnevernspedagog eller sosionom, og de har med seg en kompetanse på utøvelse av faglig skjønn. Utøvelsen av skjønn foregår da på bakgrunn av den kunnskapen og erfaringen de som profesjonelle har med seg inn i sin lederrolle. Skjønnet knyttes til å definere hva problemet består i, vurdering av hvilke løsninger som finnes og beslutning av hvilken handling eller tiltak som skal iverksettes (Molander \& Terum, 2013a, s. 16). Dette støttes av Bjørnebekk (2010) sine funn om at det barnevernsfaglige skjønnet utøves ut fra forståelser av kunnskap der skjønnet skal være upersonlig, kognitivt og rasjonelt, og hvor fakta skilles fra vurderinger.

Skjønn som prosess framstår sjelden som ren analyse eller ren intuisjon, og skjønnsutøvelse i praksis utgjør en blanding av disse elementene. Det gjør det også hos barnevernslederen, selv om de bevisste prosessene utgjør hovedtyngden. Ifølge Kirkhaug (2017) vil blandingsforholdet variere med situasjonen. Barnevernledere beskriver at de i sin skjønnsutøvelse også vektlegger egne erfaringer. Det utgjør i stor grad de intuitive og tause prosessene som barnevernleders skjønnsutøvelse består av. Årsaken til at barnevernlederne vektlegger bruk av egen erfaring i sin skjønnsut øvelse i så stor grad, kan være at allmenne handlingsregler sjelden gir klare svar på hva som bør gjøres i konkrete situasjoner (Molander \& Terum, 2013b). Her kommer dømmekraften hos lederen til anvendelse, gjennom å utøve skjønn i forhold til å fatte beslutninger til det beste for den det gjelder samtidig som egne erfaringer ligger til grunn.

\section{Handlingsrom med organisatoriske begrensninger}

Betingelser for skjønn kan deles inn i personlige og organisatoriske forutsetninger.

Betingelsesperspektivet beskriver de organisatoriske forutsetningene som strukturelle og kulturelle trekk ved organisasjonen og posisjonen skjønnet utøves i (Kirkhaug, 2017). Det handler blant annet om hvordan barneverntjenesten er organisert og hvilke krav som stilles til det kommunale barnevernet. Barnevernlederne beskriver en hverdag hvor de er opptatt av daglig drift, som de selv sier "fanger deg som leder". Lederne er i varierende grad involvert i konkrete barnevernssaker, men i veiledning og oppfølging av ansatte fokuseres det i hovedsak på barnevernsfaglige spørsmål. Barnevernlederne fungerer i stor grad som tilretteleggere som sørger for og bidrar til at de ansatte får utført jobben sin på best mulig måte. De er i mindre grad opptatt av det helhetlige perspektivet på tjenesten de leder, på utvikling og mål for virksomheten.

De organisatoriske forutsetningene handler også om barnevernleders handlingsrom. Rommet for skjønnsut øvelse oppleves av barnevernlederne som stort. Dette opplever de til tross for at utviklingen i barnevernet går i retning av at skjønnet utfordres i stadig større grad. Skjønnet utfordres ovenfra, ved at struktur og standardisering blir vektlagt i større grad (Ponnert \& Svensson, 2016), og nedenfra ved at forventninger fra foreldre og brukere ikke innfris (Moe \& Gotvassli, 2017). Lederne 
påpeker at lovverk og retningslinjer begrenser rommet for skjønn, men hevder likevel at de i noen tilfeller har et for stort rom for skjønn. Det skyldes blant annet uklart lovverk. Rommet for skjønnsut $\varnothing v e l s e$ antas å være mindre i stabile situasjoner enn i situasjoner preget av endring og krise. Ledere med liten erfaring kan ofte oppleve at handlingsrommet er mindre enn ledere med lang erfaring (Olaison et al., 2018). Dette ser ikke ut til å stemme for barnevernslederen. Barnevernlederne kan sies å lede under relativt stabile betingelser. I tillegg mente alle barnevernlederne at de hadde stort rom for skjønn, uavhengig av antall års erfaring som barnevernsleder. Rommet for skjønnsutøvelse vil ofte oppleves som stort dersom krav og forventninger ovenfra er lite konsistente og virkelighetsnære (Hagebakken \& Nilsen, 2017). Barnevernleders opplevelse av hvor stort rommet er for bruk av skjønn ser ut til å være situasjonsavhengig. I de situasjoner som er krevende og hvor vanskelige avgjørelser må tas, oppleves rommet for skjønn som for stort fordi rammene ikke gir tydelige føringer for skjønnsbruk og handlingsvalg i hverdagen.

Hos barnevernlederne er den barnevernfaglige delen av lederrollen i fokus også når de skal beskrive hva som påvirker og begrenser skjønnsutøvelsen. En del av begrensningene barnevernslederne trekker fram er ikke nødvendigvis begrensninger på selve skjønnsut øvelsen, men utgjør mer en begrensning på handlingsrommet og de handlingsalternativer leder opplever at hun har. Barnevernleder opplever at få handlingsalternativer og dermed manglende handlingsrom legger begrensninger på skjønnsutøvelsen. Det betyr at barnevernlederne opplever at det i stor grad er de organisatoriske forutsetningene som påvirker og begrenser skjønnsutøvelsen. Opplevelsene til barnevernlederne viser at skjønnets begrensninger ikke alltid lar seg skille fra skjønnets handlingsrom. Figur 2 viser hva barnevernlederne framhever som faktorer som påvirker og begrenser skjønnsut $ø$ velsen. Vi har organisert disse ut fra personlige og organisatoriske forutsetninger.

[Figur 2; Barnevernleders oppfatning av hva som påvirker og begrenser skjønnsutøvelsen omtrent her]

Figuren viser en klar overvekt av organisatoriske forutsetninger som oppleves som begrensninger for skjønnsutøvelsen. Konteksten for utøvelse av skjønnet, den kommunale barneverntjenesten, danner ramme for ledernes ut øvelse av skjønn. Denne konteksten aktiverer ulike begrensninger for skjønn, og skaper dermed ulike betingelser og handlingsrom for skjønn. Barnevernslederne opplever få eller ingen personlige forutsetninger som begrensende på skjønnet. Kompetanse nevnes ikke som en begrensning. Derimot oppleves de organisatoriske forutsetningene som begrensende for 
skjønnsut øvelsen og handlingsrommet, og dermed den friheten de har til å velge virkemidler og fatte beslutninger.

\section{Avslutning}

I artikkelen har vi undersøkt i hvilke sammenhenger lederskjønn utøves, hva som påvirker

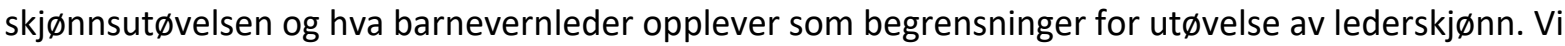
har også undersøkt hva barnevernleder gjør når hun praktisk utøver skjønn. Vi har funnet at skjønn praktiseres som et kollektivt skjønn og at det er organisatoriske begrensninger på skjønnsut øvelsen.

Ledelse av barnevernet er utfordrende, og barnevernlederne har over tid fått utvidet sitt ansvarsområde til å gjelde både fag, personal og økonomi. Barnevernlederen beskriver en hverdag som er uoversiktlig og kompleks, med økte forventninger og kryssende styringskrav. Det utfordrer lederskjønnet. Likevel opplever barnevernlederne rommet for skjønnsutøvelse som stort. Rommet for skjønn representerer noen muligheter, men hvordan mulighetene tas i bruk er dels opp til den enkelte. Det varierer fra barnevernleder til barnevernleder hvilke premisser de vektlegger og hvordan de etterlever dem. Til tross for et stort rom for skjønn, oppleves en del begrensninger. Krav og forventninger ovenfra oppleves ikke alltid som konsistente og virkelighetsnære, og rammene gir i liten grad tydelige føringer for skjønnsbruk og handlingsvalg i hverdagen. Det er de organisatoriske forholdene som oppleves som begrensende på skjønnsutøvelsen, ikke de personlige. Egen kompetanse og andre personlige forutsetninger anses i liten grad som begrensninger for skjønnsutøvelsen.

I Barne- og likestillingsdepartementets kompetansestrategi for det kommunale barnevernet 20182024 (Barne- og likestillingsdepartementet, 2017) framheves en styrking av barnevernleders kompetanse. Nasjonale krav og forventninger til ledelse i barnevernet er tydeliggjort (Barneungdoms- og familiedirektoratet, 2017). Det vektlegges en profesjonalisering av lederrollen, med $\varnothing \mathrm{kt}$ rolleforståelse hos lederne og vekt på en effektiv og tydelig ledelse.

Barnevernleder ser i liten grad egen kompetanse som begrensing på skjønnet. Det er forståelig siden skjønnet utøves kollektivt og man derfor kan bruke av en felles kompetanse. De organisatoriske begrensningene oppleves da tydeligere. Samtidig som et kollektivt skjønn kan minske ulempene ved skjønnsbruk, som for eksempel vilkårlighet i saksbehandling og privatisering av beslutningstaking, kan det vanskeliggjøre arbeidet med å utvikle en tydeligere lederrolle. Barnevernleders skjønnsut øvelse høster av mange kilder og skillet mellom lederskjønn og faglig skjønn er utydelig. Det bidrar til en uklar lederrolle. 
Styrking av kompetansen hos barnevernlederne er av stor betydning. Utfordringen er hvilket kunnskapssyn man baserer kompetansehevingen på. Dersom kompetansehevingen er basert på en byråkratisk forståelse av kunnskap (Bjørnebekk, 2010), hvor skjønnsutøvelsen blir en teknisk øvelse som er upersonlig, kognitiv og rasjonell utfordrer det arbeidet med å skape god ledelsespraksis i barnevernet. Lederskjønnet påvirkes av personlige, relasjonelle og situasjonelle faktorer, og konteksten for utøvelse av ledelse anses som viktig. For å tydeliggjøre lederrollen i barnevernet bør man derfor også vektlegge de organisatoriske forutsetningene for ut øvelse av ledelse og lederskjønn. Kompetanse og rammer for å nyttegjøre seg kompetansen må sees i sammenheng. Gode organisatoriske rammer og betingelser utgjør en forutsetning for at den $\varnothing$ kte lederkompetansen skal bidra til en profesjonalisering av ledelsen i barnevernet. Det er utfordrende å ut $\varnothing v e$ en profesjonell og tydelig ledelse dersom ikke de organisatoriske forholdene underst $\varnothing$ tter dette. 


\section{Referanser}

Abbott, A. (1988). The system of professions : an essay on the division of expert labor. Chicago: University of Chicago Press

Agevall, L. (2000). Hur välfärd organiseras - Spelar det någon roll? Statsvetenskaplig tidskrift, 103(1), 18-42.

Andersen, O. J., Moldenæs, T. \& Torsteinsen, H. (2017). Lederes skjønnsutøvelse og situasjon - en sammenheng? I O. J. Andersen, T. Moldenæs \& H. Torsteinsen (Red.), Ledelse og skjønnsutøvelse. Analyse, intuisjon og forhandlinger (s. 341-356). Bergen: Fagbokforlaget.

Askeland, H. (2016). Hverdagsledelse: Diakoni, verdier og ledelse i praksis Det teologiske Menighetsfakultetet, Oslo.

Askeland, H., Blomander, C. \& Aasen, A. (2015). Jakten på ledelse i praksis. Semistrukturert følgeobservasjon som metode innenfor ledelsesforskning. Nordiske Organisasjonsstudier, 17(1), 330.

Barne- og likestillingsdepartementet. (2017). Mer kunnskap - bedre barnevern. Kompetansestrategi for det kommunale barnevernet 2018-2024.

Barne- ungdoms- og familiedirektoratet. (2017). Operativ ledelse i barnevernet. Beskrivelse av krav og forventninger. Oslo.

Berg, L. N. (2017). Skjønn som individuell og kollektiv praksis i sykehusledelse. I O. J. Andersen, T. Moldenæs \& H. Torsteinsen (Red.), Ledelse og skjønnsutøvelse (s. 112-131). Bergen: Fagbokforlaget.

Bjørnebekk, W. (2010). Utfordringer for utviklingen av et kunnskapsbasert barnevern. Fontene forskning 1/10, 91-103. Hentet fra http://fonteneforskning.no/forskningsartikler/utfordringer-for-utviklingen-av-etkunnskapsbasert-barnevern-6.19.264804.9be01ebe50

Boyatzis, R. E. (1998). Transforming qualitative information : thematic analysis and code development. Thousand Oaks, Calif: Sage Publications.

Colby Peters, S. (2018). Defining social work leadership: a theoretical and conceptual review and analysis. Journal of Social Work Practice, 32(1), 31-44. https://doi.org/10.1080/02650533.2017.1300877

Dworkin, R. (1978). Taking rights seriously. London: Duckworth.

Døving, E., Elstad, B. \& Storvik, A. (2016). Profesjon, ledelse og organisasjon - perspektiver og begreper. I E. Døving, B. Elstad \& A. Storvik (Red.), Profesjon og ledelse (s. 31-60). Bergen: Fagbokforlaget.

Espedal, B. (2015). Is managerial discretion good or bad for organizational adaptiveness? Leadership, 11(2), 142-157.

Espedal, B. \& Kvitastein, O. A. (2012). Rom for læring: betydningen av handlingsrom for ledelse. Magma - Tidsskrift for økonomi og ledelse, 15(8), 30-39.

Evans, T. (2011). Professionals, Managers and Discretion: Critiquing Street-Level Bureaucracy. British Journal of Social Work, 41(2), 368-386. https://doi.org/10.1093/bjsw/bcq074

Evans, T. \& Harris, J. (2004). Street-Level Bureaucracy, Social Work and the (Exaggerated) Death of Discretion. The British Journal of Social Work, 34(6), 871-895. https://doi.org/10.1093/bjsw/bch106

Freidson, E. (2001). Professionalism : the third logic. Cambridge: Polity Press.

Gaim, M. \& Wåhlin, N. (2016). In search of a creative space: A conceptual framework of synthesizing paradoxical tensions. Scandinavian Journal of management, 32(1), 33-44. https://doi.org/https://doi.org/10.1016/j.scaman.2015.12.002

Goodin, R. E. (1986). Welfare, Rights and Discretion. Oxford Journal of Legal Studies, 6(2), 232-261.

Grimen, H. (2009). Skjønn som resonneringsform. I Profesjonsledelse og kunnskapsorganisering. Bergen: FORPRO. Hentet fra https://profesjon.no/wpcontent/uploads/2012/09/19124a5241f1c7cf7.pdf 
Grimen, H. \& Molander, A. (2008). Profesjon og skjønn. I A. Molander \& L. I. Terum (Red.), Profesjonsstudier. Oslo: Universitetsforlaget.

Hagebakken, G. \& Nilsen, E. A. (2017). Førstelinjeledernes handlingsrom - bur eller ballsal? I O. J. Andersen, T. Moldenæs \& H. Torsteinsen (Red.), Ledelse og skjønnsutøvelse. Analyse, intuisjon, forhandlinger. Bergen: Fagbokforlaget.

Hollis, M. (2002). The Philosophy of social science: an introduction (Rev. and updated utg.). Cambridge: Cambridge University Press.

Hood, C. (1991). A public management for all seasons? Pubblic administration, 69(1), 3-19. https://doi.org/10.1111/j.1467-9299.1991.tb00779.x

Hood, C. \& Peters, G. (2004). The Middle Aging of New Public Management: Into the Age of Paradox? Journal of Public Administration Research and Theory (JPART), 14(3), 267-282. https://doi.org/https://doi.org/10.1093/jopart/muh019

Hutzschenreuter, T. \& Kleindienst, I. (2013). (How) Does discretion change over time? A contribution toward a dynamic view of managerial discretion. Scandinavian Journal of management, 29, 264-281.

Højberg, H. (2014). Hermeneutik. Forståelse og fortolkning i samfundsvidenskaberne. I L. Fuglesang, P. Bitsch Oslen \& K. Rasborg (Red.), Videnskapsteori i samfundsvidenskaberne. På tvers av fagkulturer og paradigmer (3.utgave. utg., s. 289-324). Fredriksberg: Samfundslitteratur.

Høybye-Mortensen, M. (2015). Decision-Making Tools and Their Influence on Caseworkers' Room for Discretion. The British Journal of Social Work, 45(2), 600-615. https://doi.org/10.1093/bjsw/bct144

Irvine, A., Drew, P. \& Sainsbury, R. (2012). 'Am I not answering your questions properly?' Clarification, adequacy and responsiveness in semi-structured telephone and face-to-face interviews. Qualitative Research, 13(1), 87-106. https://doi.org/https://doi.org/10.1177/1468794112439086

Justesen, L. \& Mik-Meyer, N. (2010). Kvalitative metoder i organisations- og ledelsesstudier. København: Hans Reitzels forlag.

Kakabadse, N. K., Lee-Davies, L. \& Kakabadse, A. (2009). Leadership discretion: a developmental experience. Strategic Change, 18(3-4), 111-124. https://doi.org/10.1002/isc.842

Kelly, J. \& Bakr Ibrahim, A. (1991). Executive behavior: Its facts, fictions, and paradigms. Business Horizons, 34(2). https://doi.org/http://dx.doi.org/10.1016/0007-6813(91)90063-2

Kirkhaug, R. (2013). Verdibasert ledelse. Betingelser for utøvelse av moderne lederskap. Oslo: Universitetsforlaget.

Kirkhaug, R. (2015). Lederskap. Person og funksjon. Oslo: Universitetsforlaget.

Kirkhaug, R. (2017). Lederskapsskjønn. I O. J. Andersen, T. Moldenæs \& H. Torsteinsen (Red.), Ledelse og skjønnsutøvelse. Bergen: Fagbokforlaget.

Kvale, S. (1990). Det kvalitative interview. I I. Andersen (Red.), Valg av organisasjonssosiologiske metoder: et kombinasjonsperspektiv. København: Samfundslitteratur.

Kvello, Ø. \& Moe, T. (Red.). (2014). Barnevernledelse. Oslo: Gyldendal akademisk.

McFadden, P., Campbell, A. \& Taylor, B. (2014). Resilience and Burnout in Child Protection Social Work: Individual and Organisational Themes from a Systematic Literature Review. British Journal of Social Work, 45(5), 1546-1563. https://doi.org/https://doi.org/10.1093/bjsw/bct210

Mintzberg, H. (2001). Managing Exceptionally. Organization Science, 12(6), 759-771.

Moe, T. \& Gotvassli, K.-Å. (2016a). Ledelse og beslutningspraksis. I Ø. Christiansen \& B. H. Kojan (Red.), Belutninger i barnevernet. Oslo: Universitetsforlaget.

Moe, T. \& Gotvassli, K.-Å. (2016b). Å lede til barns beste - Hvordan kan lederutdanning i barnevernet svare på barnevernets behov for $\varnothing \mathrm{kt}$ lederkompetanse? Tidsskriftet Norges Barnevern, 92(0304), 166-182. https://doi.org/10.18261/issn.1891-1838-2016-03-04-03

Moe, T. \& Gotvassli, K.-Å. (2017). Barnevernledelse - skjønnsutøvelse og ansvarliggjøring. I O. J. Andersen, T. Moldenæs \& H. Torsteinsen (Red.), Ledelse og skjønnsutøvelse (s. 132-155). Bergen: Fagbokforlaget. 
Moe, T. \& Valstad, S. J. (2014). Lederutfordringer, lederansvar og en modell for barnevernledelse. I $\varnothing$. Kvello \& T. Moe (Red.), Barnevernledelse (s. 22-40). Oslo: Gyldendal Norsk Forlag.

Molander, A. (2011). Efter eget skön:om beslutsfattande i professionellt arbete. Socialvetenskaplig tidsskrift, 4, 320-335.

Molander, A. \& Terum, L. I. (2013a). Profesjonsstudier - en introduksjon. I A. Molander \& L. I. Terum (Red.), Profesjonsstudier (3. utg., s. 13-28). Oslo: Universitetsforlaget.

Molander, A. \& Terum, L. I. (Red.). (2013b). Profesjonsstudier (3. utg.). Oslo: Universitetsforlaget.

Norsk barnevernlederorganisasjon. (13.04.2018). Medlemsliste. Hentet fra http://www.barnevernledere.no/medlemmer-nobo/\#medlemsliste/?view 25 page=1

Novick, G. (2008). Is There a Bias Against Telephone Interviews in Qualitative Research? Research in Nursing \& Health, 31, 391-398. https://doi.org/10.1002/nur.20259

Nyathi, N. (2018). Child protection decision-making: social workers' perceptions. Journal of Social Work Practice, 32(2), 189-203. https://doi.org/10.1080/02650533.2018.1448768

Olaison, A., Torres, S. \& Forssell, E. (2018). Professional discretion and length of work experience: what findings from focus groups with care managers in elder care suggest. Journal of Social Work Practice, 32(2), 153-167. https://doi.org/10.1080/02650533.2018.1438995

Olsen, H. (2003). Kvalitative analyser og kvalitetssikring. Tendenser i engelsksproget og skandinavisk metodelitteratur. Sociologisk Forskning, 40(1), 68-103.

Pettersen, I. J. \& Solstad, E. (2014). Managerialism and Profession-Based Logic: The Use of Accounting Information in Changing Hospitals. Financial Accountability \& Management, 30(4).

Ponnert, L. \& Svensson, K. (2016). Standardisation-the end of professional discretion? European Journal of Social Work, 19(3-4), 586-599. https://doi.org/10.1080/13691457.2015.1074551

Popa, A. B. (2012). A Quantitative Analysis of Perceived Leadership Practices in Child Welfare Organizations. Journal of Public Child Welfare, 6(5), 636-658.

https://doi.org/10.1080/15548732.2012.723974

Prop. 106 L. (2012-2013). Endringer i barnevernloven. Oslo: Barne-, likestillings- og inkluderingsdepartementet Hentet fra https://www.regjeringen.no/no/dokumenter/prop106-I-20122013/id720934/?ch=1\&q=

Riksrevisjonen. (2012). Unders økelse om det kommunale barnevernet og bruken av statlige virkemidler (Dokument 3:12 (2011-2012)). Oslo: Riksrevisjonen.

Shanks, E., Lundström, T. \& Wiklund, S. (2015). Middle Managers in Social Work: Professional Identity and Management in a Marketised Welfare State. The British Journal of Social Work, 45(6), 1871-1887. https://doi.org/10.1093/bjsw/bcu061

Shotter, J. \& Tsoukas, H. (2014). In Search of Phronesis: Leadership and the Art of Judgment. Academy of Management Learning \& Education, 13(2), 224-243.

Statens Helsetilsyn. (2012). Oppsummering av landsomfattende tilsyn med kommunalt barnevern 2011 - undersøkelse og evaluering. Rapport 2/2012. Oslo: Statens Helsetilsyn.

Sturges, J. E. \& Hanrahan, K. J. (2004). Comparing Telephone and Face-to-Face Qualitative Interviewing: a Research Note. Qualitative Research, 4(1), 107-118. https://doi.org/https://doi.org/10.1177/1468794104041110

Sullivan, W. P. (2016). Leadership in the Social Work: Where Are We? Journal of Social Work Education, 52(sup1), 51-61. https://doi.org/10.1080/10437797.2016.1174644

Sweet, L. (2002). Telephone interviewing: is it compatible with interpretive phenomenological research? Contemporary Nurse, 12(1), 58-63. https://doi.org/ 10.5172/conu.12.1.58

Thagaard, T. (2016). Systematikk og innlevelse. En innføring i kvalitativ metode. (4. utg.). Bergen: Fagbokforlaget.

Toresen, G. (2014). Barnevernlederen - et kommunalt kinderegg? I T. Moe \& $\varnothing$. Kvello (Red.), Barnevernledelse. Oslo: Gyldendal akademisk.

Tracy, S. J. (2010). Qualitative Quality: Eight "Big-Tent" Criteria for Excellent Qualitative Research. Qualitative Inquiry, 16(10), 837-851. https://doi.org/10.1177/1077800410383121 
Tredget, D. A. (2010). Practical wisdom and the Rule of Benedict. Journal of Management Development, 29(7/8), 716-723.

Trier-Bieniek, A. (2012). Framing the telephone interview as a participant-centred tool for qualitative research: a methodological discussion. Qualitative Research, 12(6), 630-644.

https://doi.org/https://doi.org/10.1177/1468794112439005

Wangrow, D. B., Schepker, D. J. \& Barker, V. L. (2015). Managerial Discretion: An Empirical Review and Focus on Future Research Directions. Journal of Management, 41(1), 99-135. https://doi.org/10.1177/0149206314554214

Ward, K., Gott, M. \& Hoare, K. (2015). Participants' views of telephone interviews within a grounded theory study. Journal of Advanced Nursing, 71(12), 2775-2785. https://doi.org/https://doi.org/10.1111/ian.12748

Wällstedt, N. \& Almqvist, R. (2015). From 'either or' to 'both and': Organisational management in the aftermath of NPM. Scandinavian Journal of Public Administration, 19(2), 7-25. 